\title{
Post-cardiac Surgery Chylopericardium
}

\author{
Shi-Min Yuan \\ Department of Cardiothoracic Surgery, The First Hospital of Putian, Teaching Hospital, Fujian Medical University, Putian, Fujian \\ Province, China
}

\begin{abstract}
Post-cardiac surgery chylopericardium is a rare complication. This systematic review included 87 articles with 119 patients of post-cardiac surgery chylopericardium. Chylopericardium developed after operations for congenital heart defect more than those for acquired heart disease, and more patients in whom post-cardiac surgery chylopericardium developed were with complex than with simple congenital heart defects. Cardiac tamponade occurred in 35 (29.4\%) patients. The onset time of chylopericardium was 18.2 days earlier in patients operated for acquired than in those for congenital heart defects. Post-cardiac surgery chylopericardium were curable to conservative treatment in most patients. The recurrence of post-cardiac surgery chylopericardium was on day $13.2 \pm 18.2$ after the initial treatment. The overall early and late mortality rates were $1.7 \%(2 / 119)$ and $1.7 \%(2 / 117)$, respectively. Most patients with post-cardiac surgery chylopericardium were diagnosed by laboratory analysis of chylous fluid. Patients with mild chylopericardium usually show good response to conservative treatment. Whereas, patients with massive chylopericardium and rapid accumulation, incurable to conservative treatment and recurrent to either conservative or surgical treatment, warrant further surgical treatment.
\end{abstract}

Key Words: Cardiac surgical procedures, Pericardial effusion, Postoperative complications.

How to cite this article: Yuan SM. Post-cardiac Surgery Chylopericardium. J Coll Physicians Surg Pak 2020; 30(06):627-632 https://doi.org/10.29271/jcpsp.2020.06.627.

\section{INTRODUCTION}

Chylopericardium is accumulation of chyle within the pericardial cavity. ${ }^{1}$ Mechanical damages to the thoracic duct or its tributaries by compression, obstruction, or rupture may result in lymphatic leakage into the pericardial cavity and lead to chylopericardium. ${ }^{2}$ The etiologies of chylopericardium can be complex and heterogeneous, being congenital, traumatic, obstructive, inflammatory, and idiopathic. ${ }^{2}$ Delayed treatment may cause fatal consequences, such as cardiac tamponade, cardiovascular compressions, hypovolemia, hyponatremia, disturbance of fluid, electroIyte, and acid-base metabolisms, and immunedeficiency. ${ }^{3}$ Postoperative chylopericardium, a type of traumatic chylopericardium, is an even rarer complication after cardiac surgery. The incidence of post-cardiac surgery chylopericardium was reported to be $0.12-1.5 \%{ }^{4}$

Due to its rarity, most reported cases were sporadic, and large series of patients were scanty. Disputes still exist concerning the etiologies, diagnoses, ideal treatments, and preventive measures; and no definite conclusions could be drawn because of the large data scatter. In this review, the objective was to provide a comprehensiveanalysis of post-cardiac surgery chylochyloperidium.

Correspondence to: Shi-Min Yuan, Department of Cardiothoracic Surgery, The First Hospital of Putian, Teaching Hospital, Fujian Medical University, Putian-351100, Fujian Province, People's Republic of China

E-mail: shiminyuan@126.com

Received: March 12, 2019; Revised: July 11, 2019;

Accepted: July 20, 2019

DOI: https://doi.org/10.29271/jcpsp.2020.06.627

\section{METHODOLOGY}

Literature regarding chylopericardium, as a complication of cardiac surgery, were retrieved from PubMed, Yahoo! search engine, and Chinese Medical Current Content (CMCC) databases for articles published from 1970 onwards. MeSH terms and keywords used to identify articles included "chylopericardium", "pericardial effusion", "cardiac surgical procedures", "congenital heartdefect", "heart/aortic/mitral/tricuspid valve", "coronary artery bypass grafting", "aorta replacement", and "heart/heart-lung transplantation". Bibliographic references helped the completeness of the literature retrieval. The search was renewed by the end of December, 2018. The screening of the bibliographic references helped in completing the literature retrieval. One hundred and seventeen articles were found related to the topic and keywords in the literature search; and 87 articles, which met the inclusion criteria during preliminary assessment, were included in the review. The exclusion criteria were articles describing: a general discussion of chylopericardium $(n=7)$, post-cardiac surgery chylothorax $(n=5)$, traumatic chylopericardium $(n=3)$, a topic irrelevant to post-cardiac surgery chylopericardium $(n=3)$, treatment of chylopericardium $(n=2)$, management of pericardial disease $(n=2)$, post-cardiac surgery tamponade $(n=2)$, post-cardiac surgery pericardial complications $(n=1)$, primary chylopericadium $(n=1)$, chylopericardium due to filariasis $(n=1)$, central venous catheter indwelling $(n=1)$, pericardiocentesis $(n=1)$, and lung transplantation $(n=1)$.

The dimension of pericardial effusion in adults were defined as: small (average depth $<1 \mathrm{~cm}$ ); moderate (average depth $=1-2$ $\mathrm{cm}$ ); and large (average depth $>2 \mathrm{~cm}$ ). ${ }^{5}$ 
Data of patients with post-cardiac surgery chylopericardium were carefully extracted for patients' demographics, clinical presentations, diagnosis, recurrence, follow-up and outcomes, etc. The quantitative indexes were expressed as mean \pm standard deviation. The intergroup differences were analysed by unpaired $t$-test. The differences of frequencies were assessed by Fisher's exact test and $p<0.05$ was considered as statistically significant. The statistic analyses were conducted by using IBMSPSS Statistics version 22.0.

\section{RESULTS}

A total of 87 articles were obtained including 119 patients with 121 chances of chylopericardium, with two of them having twice of chylopericardium six months apart between two heart operations. ${ }^{6,7}$ The sources of these articles were PubMed for 54 (62.1\%), Yahoo! search engine for 16 (18.4\%), Chinese Medical Current Content (CMCC) for 7 (8.0\%), and bibliographic reference for 10 (11.5\%) articles, respectively.

Patient gender was available for 102 patients. There were 61 $(59.8 \%)$ male and $41(40.2 \%)$ female patients $\left(\chi^{2}=7.8\right.$, $p=0.008)$. The patients were of the age of $24.1 \pm 24.0$ years (range, 0-77; median, 20) $(n=106)$. The age of the newborns, who were small for dates, was recorded as zero. ${ }^{8}$ There were 56 (50.9\%) pediatrics and 54 (49.1\%) adults, while nine patients' age was not indicated. The 30 infants that were included in this study accounted for $53.6 \%$ (30/56) of the pediatrics and $27.3 \%$ (30/110) of whole patient population. There were no significant difference in age between male and female patients (20.7 \pm 23.8 years vs. $26.4 \pm 24.3$ years, $p=0.300$ ).

The underlying cardiac diseases for a cardiac operation were known for 116 patients, including congenital heart defects $(n=64)$, acquired heart disease $(n=48)$, and combined congenital and acquired heart diseases $(n=4)\left(\chi^{2}=74.9, p\right.$ $<0.001$ ). Heart valve disorder was the most common cause of heart operation for acquired heart disease. There was no significant difference in the prevalence between acquired mitral valve disorders and aortic valve disorders including aortic valve replacement or repair involved in aorta replacement procedures[63.3\% (19/30) vs. 36.7\%(11/30), $\left.\chi^{2}=3.9, p=0.067\right]$.

The onset time of chylopericardium was $22.1 \pm 54.0$ days $(n=84)$ after cardiac operations. It was recorded as zero when chylopericardium occurred during operation. The onset time of postoperative chylopericardium was 18.2 days earlier in patients undergoing an operation for acquired heart disease than in those for congenital, without statistical significance (14.3 \pm 16.7 days vs. $32.5 \pm 78.7$ days, $p=0.143$ ).

There were 68 clinical symptoms reported for 61 (51.3\%) patients. Dyspnoea was the most common symptom representing $35.3 \%$ (24/68), followed by sporadic circulatory or constitutional symptoms. Change of color in drained material and increased pericardial drainage amount were the two most common clinical observations of the patients setting representing $34.8 \%(16 / 46)$ and $19.6 \%$ (9/46), respectively.
Cardiac tamponade occurred on 37 occasions in 35 (29.4\%) patients, with two patients having twice tamponades. ${ }^{9,10}$ The tamponade was non-chylous in $3(8.6 \%)$ patients, while chylous tamponade was present in 33 (94.3\%) patients on 34 (91.9\%) occasions. Tamponade occurred on day $7.4 \pm 26.1$ (range, -5-145; median, 0$)(n=32)$ with reference to the onset time of chylopericardium (timing of non-chylous tamponade developed before the occurrence of chylopericardium was recorded as a minus). In 18 (18/35, 51.4\%) patients, tamponade occurred the same time as onset of chylopericardium, and the timing of tamponade was thus recorded as zero.

Diagnosis: The timing of diagnosis, described time interval between the onset of chylopericardium to the establishment of the definite diagnosis, was $8.5 \pm 11.0$ days $(n=52)$.

Immediate diagnosis was made in 29 (29/52, 55.8\%) of these patients, whose timing of diagnosis was recorded as zero. An initial misdiagnosis was made in $7(7 / 119,5.9 \%)$ patients. They were misdiagnosed as: cardiac dysfunction $(n=2),{ }^{11,12}$ postpericardiotomy syndrome $(n=2),{ }^{13,14}$ heart failure with respiratory infection $(n=1),{ }^{15}$ postpericardiotomy syndrome or antigen-antibody reaction $(n=1),{ }^{16}$ and heart failure with postpericardiotomy syndrome $(n=1),{ }^{17}$ respectively.

The electrocardiographic results were reported in $6(5.0 \%)$ patients, with normal sinus rhythm in $1(16.7 \%)$ patient, ${ }^{18}$ and non-specific changes in $5(83.3 \%)$ patients. ${ }^{4,8,19-21}$ Results of chest X-ray were reported in $32(26.9 \%)$ patients, showing an enlargement of cardiac silhouette in 27 (84.4\%) patients, an enlarged mediastinum in $3(9.4 \%)$ patients, ${ }^{22-24}$ and both enlargement of cardiac silhouette and enlarged mediastinum in 1 (3.1\%) patient, ${ }^{25}$ and a bilateral chylothorax in $1(3.1 \%)$ patient. $^{26}$

Inspections of the pericardial effusions revealed large/massive amount, milky appearance, positive chylomicrons, Sudan III stain and triglyceride, and increased triglyceride, cholesterol and white blood cell counts in most of the cases (Tablel). The triglyceride value was extremely high, up to $1255.7 \mathrm{~g} / \mathrm{L}$ equivalent to $125,570 \mathrm{mg} / \mathrm{dL}$, in one patient, ${ }^{14}$ and this value was excluded from the statistical analysis. Location of the chylous leakage was attempted with 23 methods in 22 patients with a failure rate of $27.3 \%$ (Tablell).

Treatment and Prognosis: The treatment was unavailable for 2 patient. In the remaining 117 patients, the initial treatment was conservative in 90 (76.9\%) patients, and it was surgical in $27(23.1 \%)$ patients $\left(\chi^{2}=67.9, p<0.001\right)$. The conservative regimens were applied in 90 patients included pericardiocentesis, pericardial drainage, fat-limited diet (low-fat and fat-free diets), medium chain fatty acid, parenteral alimentation, and somatostatin/octreotide use. The dietary therapy lasted for $13.7 \pm 7.9$ days $(n=7)$ with an ineffective rate of $3.1 \%(2 / 65)$. The parenteral alimentation lasted for $10.2 \pm 5.1$ days $(n=6)$. Somatostatin/octreotide was used in 8 patients ${ }^{26-33}$ for 9-14 days with an effective rate of $75 \%$ and an ineffective rate of $25 \%$ at a dose of octreotide $100 \mathrm{mg}$ three times daily ${ }^{33}$ and somatostatin 3.5 
$\mathrm{mg} / \mathrm{kg} / \mathrm{hour} .{ }^{26}$ Conservative treatment was sustained for 19.0 \pm 17.3 days (range, 2-90; median, 14$)(n=52)$, and it was ineffective in $25(25 / 90,27.8 \%)$ patients.

Table I. Inspections of pericardial effusions.

\begin{tabular}{|c|c|}
\hline Inspection & Result \\
\hline $\begin{array}{l}\text { Size of pericardial effusion } \\
(\mathrm{mm})\end{array}$ & $\begin{array}{l}35.3 \pm 24.0 \text { (range, } 11-80 ; \text { median, } 22) \\
(n=9)\end{array}$ \\
\hline Large/massive & $34(79.1)$ \\
\hline Moderate & $\begin{array}{l}2 \text { (4.7) (one of them developed into large } \\
\text { pericardial effusion later) }\end{array}$ \\
\hline Mild & $1(2.3)$ \\
\hline Unspecified & $6(14.0)$ \\
\hline Nature & $46(100)$ \\
\hline Non-chylous & $1(2.2)$ \\
\hline Chylous & $45(97.8)$ \\
\hline Color & $64(100)$ \\
\hline Milky & $23(35.9)$ \\
\hline Chylous & $14(21.9)$ \\
\hline Milky white & $4(6.3)$ \\
\hline Milky yellowish & $3(4.7)$ \\
\hline Opalescent & $3(4.7)$ \\
\hline Whitish & $3(4.7)$ \\
\hline Yellowish & $2(3.1)$ \\
\hline Blood-tinged \& turbid & $1(1.6)$ \\
\hline Others & $11(17.2)$ \\
\hline Color change & $8(100)$ \\
\hline From sanguineous to milky & $3(37.5)$ \\
\hline From serosanguineous to milky & $3(37.5)$ \\
\hline From white to serous & $1(12.5)$ \\
\hline From clear to milky & $1(12.5)$ \\
\hline Time of color change (days) & $7.0 \pm 5.5$ (range, $1-14 ;$ median, 6.5$)(n=4)$ \\
\hline \multicolumn{2}{|l|}{ Qualitative analyses } \\
\hline Chylomicrons & $14(12.3)$ \\
\hline Sudan III stain & $10(8.8)$ \\
\hline Positive for fat globules & $9(90)$ \\
\hline Negative & $1(10)$ \\
\hline Culture & $30(26.3)$ \\
\hline Negative & $30(100)$ \\
\hline Triglyceride & $47(40.5)$ \\
\hline Negative & $6(12.8)$ \\
\hline Positive & $41(87.2)$ \\
\hline Associated pleural effusions & $33(28.4)$ \\
\hline Non-chylous & $2(6.1)$ \\
\hline Chylous (chylothorax) & $31(93.9)$ \\
\hline $\begin{array}{l}\text { Interval between development } \\
\text { of chylopericardium and of } \\
\text { pleural effusions (days) }\end{array}$ & $\begin{array}{l}1.5 \pm 16.8 \text { (range, }-47-30 ; \text { median, } 0) \\
(n=15)\end{array}$ \\
\hline \multicolumn{2}{|l|}{ Quantitative analyses } \\
\hline Triglyceride (mg/dL) & $\begin{array}{l}1003.5 \pm 792.3 \text { (range, 74-3363; median, } \\
743.4)(n=39)\end{array}$ \\
\hline Cholesterol (mg/dL) & $\begin{array}{l}81.8 \pm 43.8 \text { (range, } 10-185.6 ; \text { median, } \\
78.5)(n=18)\end{array}$ \\
\hline Protein (mg/dL) & $\begin{array}{l}2781.6 \pm 2458.8(\text { range, 2.7-7400; } \\
\text { median, 2039) }(n=14)\end{array}$ \\
\hline (White blood) cell count $\left(/ \mathrm{mm}^{3}\right)$ & $\begin{array}{l}8060.0 \pm 12040.5(\text { range, } 540-40120 \\
\text { median, 2900) }(n=11)\end{array}$ \\
\hline Lymphocyte (\%) & $\begin{array}{l}91.1 \pm 10.5 \text { (range, 70-98; median, 95) } \\
(n=6)\end{array}$ \\
\hline
\end{tabular}

A total of $55(46.2 \%)$ patients received a surgical treatment, including $27(49.1 \%)$ patients with an initial surgical treatment, 24 $(43.6 \%)$ patients with a further surgical treatment for those with an ineffectively conservative treatment, and $4(7.3 \%)$ patients with a further surgical treatment for the recurrent patients following a conservative treatment. Most of the surgical procedures were performed via a median sternotomy (Table III).

Surgical treatment included thoracic duct ligation (including mass ligation, repeated ligations, ligation with pleural abrasion, and ligation with bioglue use, Table IV), percutaneous thoracic duct embolisation, pericardial window creation, and surgical drainage/evacuation.

Table II. Location of the chylous leakage in 22 patients.

\begin{tabular}{|l|l|}
\hline Location of the chylous leakage & $\mathbf{n}(\%)$ \\
\hline Attempt of chylous leakage location & $22(100)$ \\
\hline By operation & $12(54.5)$ \\
\hline By lymphangiogram & $7(31.8)$ \\
\hline By lymphoscintigraphy & $1(4.5)$ \\
\hline By magnetic resonance thoracic ductograph & $1(4.5)$ \\
\hline By computed tomography \& operation & $1(4.5)$ \\
\hline Failure of location of chylous leakage & $6(27.3)$ \\
\hline By lymphangiogram & $2(33.3)$ \\
\hline By operation & $4(66.7)$ \\
\hline Leak locations & $11(50)$ \\
\hline Below the carina at $T_{6}$ & $2(18.2)$ \\
\hline At $T_{9} / T_{10}$ & $1(9.1)$ \\
\hline At the superior margin of the pericardium & $1(9.1)$ \\
\hline In the periaortic fat & $1(9.1)$ \\
\hline In the thymic lobe & $1(9.1)$ \\
\hline At the superior vena cava & $1(9.1)$ \\
\hline $\begin{array}{l}\text { Posterior to the inferior vena cava (caval occlusion } \\
\text { tapes) }\end{array}$ & $1(9.1)$ \\
\hline At the clamping site of aorta & $1(9.1)$ \\
\hline $2-3$ cm above diaphragm on pericardium & $1(9.1)$ \\
\hline $\begin{array}{l}\text { In an anomalous net of mediastinal lymphatic } \\
\text { vessels }\end{array}$ & $1(9.1)$ \\
\hline
\end{tabular}

Table III. Surgical approaches in 40 patients.

\begin{tabular}{|l|l|}
\hline Surgical approach & $\mathbf{n}(\%)$ \\
\hline Sternotomy & $\begin{array}{l}15(37.5) \text { (one of them had twice sternotomies, and } \\
\text { another had a median sternotomy at first operation } \\
\text { and a subxiphoid incision at the second) }\end{array}$ \\
\hline Left anterior thoracotomy & $\begin{array}{l}4(10.0) \text { (one of them was left anterior video- } \\
\text { assisted thoracic surgery) }\end{array}$ \\
\hline Right thoracotomy & $\begin{array}{l}4(10.0) \text { (one patient had twice right thoraco- } \\
\text { tomies) }\end{array}$ \\
\hline Left anterior \& posterolateral & $1(2.5)$ \\
\hline thoracotomy & $1(2.5)$ \\
\hline Left thoracotomy & $1(2.5)$ \\
\hline Bilateral thoracotomy & $1(2.75)$ \\
\hline Thoracotomy side unknown & $13(32.5)$ \\
\hline Subxiphoid incision &
\end{tabular}


Table IV. Thoracic duct ligation level/location in 18 patients.

\begin{tabular}{|l|c|}
\hline Ligation level/location & $\mathbf{n}(\%)$ \\
\hline At the thymic gland & $6(33.3)$ \\
\hline At the diaphragmatic level & $4(22.2)$ \\
\hline Unspecified low-level ligation & $1(5.6)$ \\
\hline In the hepatic coronary ligament & $1(5.6)$ \\
\hline At the pleural surface & $1(5.6)$ \\
\hline In the thymic tissue and caval encirclement & $1(5.6)$ \\
\hline Posterior to the inferior vena cava & $1(5.9)$ \\
\hline Left lobe of the thymus \& above the innominate vein & $1(5.6)$ \\
\hline Below the azygos vein & $1(5.6)$ \\
\hline Thymus gland remnants \& pericardial edges & $1(5.6)$ \\
\hline
\end{tabular}

Table V: The patients' outcomes, $n(\%)$.

\begin{tabular}{|l|c|c|c|c|}
\hline Outcome & Conservative & Surgical & $\boldsymbol{\chi}^{2}$ & $\boldsymbol{p}$ value \\
\hline Cured & $48(51.6)$ & $17(60.7)$ & 0.7 & 0.517 \\
\hline Improved & $0(0)$ & $1(3.6)$ & 3.4 & 0.231 \\
\hline Ineffective & $26(28.0)$ & $5(17.9)$ & 1.2 & 0.333 \\
\hline Recurrent & $15(16.1)$ & $5(17.9)$ & 0.1 & 0.779 \\
\hline Died & $2(2.2)$ & $0(0)$ & 0.6 & 1.000 \\
\hline Unknown & $2(2.2)$ & $0(0)$ & -- & -- \\
\hline
\end{tabular}

Hospitalisation after surgical treatment did not differ from that of patients receiving a conservative treatment $(19.0 \pm 17.3$ days vs. $12.0 \pm 9.8$ days, $p=0.130)$. Surgical treatment was ineffective in $5(5 / 27,18.5 \%)$ patients, who were finally cured by further surgical or conservative (some patient with somatostatin) treatments. Chylopericardium recurred in 20 (20/119, $16.8 \%$ ) patients for totally 33 times ( 1.65 times per patient) on day $13.2 \pm 18.2(n=20)$ after the initial treatment. All recurrent patients, but one, eventually recovered after further strenuous treatment and one patient recovered spontaneously. ${ }^{34}$ The refractory chyloperidium patients unresponsive to initial treatment was finally cured by pleuroperitoneal shunt placement ${ }^{35}$ and percutaneous thoracic duct embolisation. ${ }^{36}$ One of the patients who were ineffective to the initial treatments had recurrent chylopericardium after further surgical treatment. He was cured by a second surgical treatment with thoracic duct ligation. ${ }^{37}$ The patients' outcomes did not differ between patients receiving a conservative and those with a surgical treatment (TableV).

The patients were under a follow-up of $15.2 \pm 18.3$ months $(n=36)$. In total, 115 (96.6\%) patients survived and 4 (3.3\%) patients died. The overall early and late mortality rates were $1.7 \%(2 / 119)$ and $1.7 \%(2 / 117)$, respectively.

\section{DISCUSSION}

Unlike the etiologies of penetrating and blunt traumatic chylopericardium, those of the post-cardiac surgery chylopericardium are direct injury (posterior mediastinal dissection, aortic clamping, or caval snares) and indirect injury (thoracic duct outflow obstruction, or increased lymphatic pressure and permeability) to the thoracic duct or its tributaries. ${ }^{38}$ Chylous leakage is often resulted from the damage to the active tissue of the thymus gland in pediatric patients, while this is less common in adult patients who are with atrophic thymus glands. ${ }^{28}$ Cardiac operation via a median sternotomy seldom injures the thoracic duct that takes a course over the anterolateral aspect of the superior mediastinum. Therefore, chylopericardium occurs less frequently in adults than in pediatrics, as more thoracotomies were used in the latter. ${ }^{32}$ Pericardiotomy or manipulation of the pericardium was reported to be an underlying cause of post-cardiac surgery chylopericardium. However, in instance of Blalock-Taussig shunt with intact pericardium, chylopericardium occurred as well. ${ }^{5}$

The speed of chylous leakage corresponds in proportion to the nature of thoracic duct injury (direct or indirect), the time of onset, the severity of clinical symptoms (with or with tamponade), and treatment of choices (conservative or surgical). A higher speed of chylous leakage should usually resort to more aggressive surgical management. ${ }^{39}$ As shown in the present study, most patients presented with dyspnoea, and others, with alternative sporadic circulatory and constitutional symptoms. Less than one-third of the patients developed cardiac tamponade from immediate postoperation to 5 months later. This was in accordance with the documented onset time of chylopericardium from immediate postoperation to 1-6 months as reported by D'Cruz et al. ${ }^{5}$

The radiographic evidence of the enlarged cardiac silhouette and widened mediastinum, ${ }^{25}$ the echocardiographic sign of pericardial effusion, ${ }^{25}$ and the milky appearance of pericardial effusions, ${ }^{40}$ may suggest the suspected or probable diagnoses of chylopericardium. The definite diagnosis of chylopericardium is usually confirmed by laboratory investigation of the pericardial fluid (presence of chylomicrons, positive Sudan III stain, and an increased triglyceride level ( $\geq 110 \mathrm{mg} / \mathrm{dL}) .{ }^{39}$ Some authors praised that lymphangiography, contrast-enhanced computed tomography, and scintigraphy were reliable diagnostic methods in the diagnosis of chylopericarium, ${ }^{39}$ whereas others did not recommend lymphangiography and computed tomography since they were less sensitive than Sudan III stain. ${ }^{40}$ In line with the latter statement, this study revealed a failure rate of lymphangiography of $28.6 \%$ (2/7). Moreover, magnetic resonance thoracic ductography may locate the thoracic duct injuries accurately. ${ }^{41}$ However, chylopericardium might be misdiagnosed and mistreated as postpericardiotomy syndrome, where the use of prednisone did not take effect. ${ }^{20}$

Postoperative chylopericardium can be managed with adequate pericardial drainage (pericardiocentesis or tube pericardiostomy), a high-protein, low-fat diet, medium-chain fatty acid, and total parenteral nutrition. ${ }^{42}$ Somatostatin ${ }^{31}$ and octreotide ${ }^{27}$ have been proposed as effective means for the patients with postoperative chylopericardium. Surgical treatment by ligation of the thoracic duct or by creation of a pericardial window is recommended when patients are incurable to a 7-day conservative therapy, or patients having recurrent chylopericardium. ${ }^{40}$ Mass 
ligation ensures complete cessation of chylous leakage; hence, right thoracotomy or right-sided video-assisted thoracic surgery are preferred surgical approaches for easy access to the thoracic duct. ${ }^{40}$ In general, chylous accumulation due to small lymphatic vessel damage can be cured by conservative management, while massive chylopericardium and rapid re-accumulation have to resort to aggressive surgical treatments. ${ }^{12}$

The main drawback of this article was the missing values of patients from different article sources, which would inevitably affect the results of statistical analysis; and as a result, multiple logisticanalysesfor predictive risks of ineffectivenessand recurrence of chylopericadium was insignificant. A further study with larger patient population is crucial for more accurate results.

\section{CONCLUSIONS}

Most patients with post-cardiac surgery chylopericardium were diagnosed, based on chemistry of chylous leakage and curable to conservative treatment. Patients incurable to conservative treatment and recurrent to either conservative or surgical treatments warrant further surgical treatment. Careful surgical manipulationsmay preventfrom post-cardiacsurgery chyloperi-cardium.

\section{ETHICALAPPROVAL:}

An ethical approval has been obtained from the Institutional Ethical Committee of the First Hospital of Putian prior to initiation of the research work.

\section{CONFLICT OF INTEREST:}

The author declares that there is no conflict of interest.

\section{AUTHOR'S CONTRIBUTION:}

SMY: Substantial contribution to the conception and design of the work; and the acquisition, analysis, and interpretation of data for the work; drafting the work and revising it critically for important intellectual content; final approval of the version to be published; agreement to be accountable for all aspects of the work in ensuring that questions related to the accuracy and integrity of any part of the work are appropriately investigated and resolved.

\section{REFERENCES}

1. Dib C, Tajik AJ, Park S, Kheir ME, Khandieria B, Mookadam F. Chylopericardium in adults. J Thorac Cardiovasc Surg 2008; 136:650-6.

2. Huang ZY, Ge JB. Current concensus on chylopericardium. Chin J Clin Med 2011; 18:48-50.

3. Koksel O, Mavioglu I, Ocal K, Gul A, Yildirim C, Ozdulger A. Traumatic chylopericardium: A case report and review of the literature. J Trauma 2007; 63:E13-6.

4. Ahmed W, Mehmood M, Rasheed K. Massive chylopericardium and chylothorax following cardiothoracic surgery. J Coll Physicians Surg Pak 2006; 16:483-4.

5. D'Cruz IA, Overton DH, Pai GM. Pericardial complications of cardiac surgery: Emphasis on the diagnostic role of echocardiography. J Card Surg 1992; 7:257-68.

6. Kanemoto S, Abe M, Ikeda A, Gomi S. Recurrent symp- tomatic chylopericardium after cardiac surgery in a child. Pediatr Cardiol 2008; 29:683-5.

7. Nguyen DM, Shum-Tim D, Dobell AR, Tchervenkov Cl. The management of chylothorax/chylopericardium following pediatric cardiac surgery: A 10-year experience. J Card Surg 1995; 10(4 Pt 1):302-8.

8. Grinberg M, Tarasoutchi F, Pomerantzeff PM, Pouza GL, Verginelli G, Jatene AD, et al. Chylopericardium. A complication following mitral valve replacement. A case report. Arq Bras Cardiol 1985; 45: 263-6. (Article in Portuguese).

9. Aymami M, Flécher E, de La Tour B, Ruggieri G, Fouquet O, Leguerrier A. Chylopericardium after cardiac surgery: successful conservative approach. Chir Thorac Cardio-Vasc 2012; 16:115-7.

10. Wierzbicki K, Mazur P, Węgrzyn P, Kapelak B. Life-threatening cardiac tamponade secondary to chylopericardium following orthotopic heart transplantation: A case report. Ann Thorac Cardiovasc Surg 2016; 22:264-6.

11. Feteih W, Rao PS, Whisennand HH, Mardini MK, Lawrie GM. Chylopericardium: A new complication of Blalock-Taussig anastomosis. J Thorac Cardiovasc Surg 1983; 85:791-794.

12. Hamilton JR, Mulholland HC, Cleland J. Chylopericardium: A rare complication of a Waterston shunt. Br Heart J 1985; 54:548-9.

13. Rose DM, Colvin SB, Danilowicz D, Isom OW. Cardiac tamponade secondary to chylopericardium following cardi ac surgery: Case report and review of the literature. Ann Thorac Surg 1982; 34:333-336.

14. Rowiński A, Wasilewski J, Lekston A, Juszczyk J. Chylopericardium as a complication of mitral valve replacement. Pol Merkur Lekarski 1999; 6:141-2. (Article in Polish).

15. Hawker PE, Cartmill TB, Celermaier JM, Bowdler JD. Chylus pericardial effusion complicating aorta-right pulmonary artery anastomosis. J Thorac Cardiovasc Surg 1972; 63: 491-4.

16. Gowani SA, Khowaja AA, Khan A, Fatimi SH. Chylopericardium: A rare complication after ventricular septal defect repair. J Pak Med Assoc 2008; 58:218-9.

17. Kansu E, Fraimow W, Smullens SN. Isolated massive chylopericardium. Complication of open heart surgery for aortic valve replacement. Chest 1977; 71:408-10.

18. Yun TJ, Cho WC, Jung SH, Seo DM, Goo HW, Kim YH. Reverse Blalock-Taussig shunt facilitates the growth of the ascending aorta after hybrid palliation. Ann Thorac Surg 2007; 83:1886-8.

19. Bakay C, Wijers TS. Treatment of cardiac tamponade due to isolated chylopericardium following open heart surgery. J Cardiovasc Surg (Torino) 1984; 25:249-51.

20. Bar-El Y, Smolinsky A, Yellin A. Chylopericardium as a complication of mitral valve replacement. Thorax 1989; 44:74-5.

21. Hargus EP, Carson SD, McGrath RL, Wolfe RR, Clarke DR. Chylothorax and chylopericardial tamponade following Blalock-Taussig anastomosis. J Thorac Cardiovasc Surg 1978; 75:642-5.

22. Pereira WM, Kalil RA, Prates PR, Nesralla IA. Cardiac tamponade due to chylopericardium after cardiac surgery. 
Ann Thorac Surg 1988; 46:572-3.

23. Schiessler A, John A, Pallua N, Bucherl ES. Chylopericardium following aorto-coronary bypass-procedure. Thorac Cardiovasc Surg 1984; 32:112-4.

24. Wong PH, Mok CK, Ong GB. Chylomediastinum: An unusual complication after mitral valve replacement. Aust N Z J Surg 1982; 52:560-1.

25. Lippmann M, Gupta K. Chylous pericardial effusion resulting in cardiac tamponade. Indian Heart J 2016; 68(Suppl 2): S161-2.

26. Rimensberger PC, Muller-Schenker B, Kalangos A, Beghetti M. Treatment of a persistent postoperative chylothorax with somatostatin. Ann Thorac Surg 1998; 66:253-4.

27. Attia A, Alsharyah H, Ghoneimy YE, Oueida F. Right chylothorax combined with chylopericardium and right diaphragmatic paralysis after coronary revascularization by bilateral internal mammary arteries. J Egypt Soc CardioThorac Surg 2016; 24:312-5.

28. Cheng CS, Uchime C, Kang D. Two cases of chylopericardium after aortic valve surgery. Asian Cardiovasc Thorac Ann 2013; 21:588-91.

29. Gyoten T, Doi T, Fukahara K, Yoshimura N. Successful surgical intervention for delayed chylopericardial tamponade following aortic valve replacement: a case report. J Cardiothorac Surg 2014; 9:190.

30. Hussain BS, Reddy SV. Chylopericardium after Cardiac Surgery. Indian J Mednodent Allied Sci 2015; 3:201-3.

31. Karaca S, Rager O, Kalangos A. Successful treatment of persistent chylopericardium with somatostatin after operation on ascending aorta. Ann Thorac Surg 2014; 97 : e97-9.

32. Likaj E, Kacani A, Dumani S, Dibra L, Refatllari A. Chylopericardium after mitral valve repair for rheumatic valve disease treated with surgery. Med Arch 2014; 68:67-8. doi: 10.5455/medarh.2014.68.67-68.
33. Szabados E, Toth K, Mezosi E. Use of octreotide in the treatment of chylopericardium. Heart Lung 2011; 40:574-5

34. Tuncay A, Akcalı Y, Serhatlıoğlu F, Özmen R, Gazioğlu Ö. Pericardioperitoneal fenestration for chylopericardium. Erciyes Med J 2016; 38:84-7.

35. Lee Y, Lee WK, Doromal N, Ganepola GAP, Hutchinson J. Cardiac tamponade resulting from massive chylopericardium after an aorto-coronary bypass operation. J Thorac Cardiovasc Surg 1987; 94:449-50.

36. Itkin M, Krishnamurthy G, Naim MY, Bird GL, Keller MS. Percutaneous thoracic duct embolization as a treatment for intrathoracic chyle leaks in infants. Pediatrics 2011; 128:e237-41.

37. Pollard WM, Schhuchmann GF, Bowen TE. Isolated chylopericardium after cardiac operations. J Thorac Cardiovasc Surg 1981; 81:943-6.

38. Delaney A, Daicoff GR, Hess PJ, Victorica B. Chylopericardium with cardiac tamponade after cardiovascular surgery in two patients. Chest 1976; 69:381-3.

39. Chaloob SS, Brown M, Stuklis RG. Chylous pericardial effusion after aortic valve replacement. Asian Cardiovasc Thorac Ann 2008; 16:e21-2.

40. Gelsomino S, Morelli A, Porreca L, Morocutti G, Da Col P, Livi U. Video-assisted thoracoscopic surgery for primary chylopericardium after orthotopic heart transplantation. J Heart Lung Transplant 2002; 21:701-5.

41. Koutsogiannidis CP, Ananiadou O, Kapsas G, Madesis A, Palladas P, Drossos G. 'Early' post-cardiotomy chylopericardium and the maging value of magnetic resonance thoracic-ductography. Heart Lung Circ 2013; 22:1033-5.

42. Denfield SW, Rodriguez A, Miller-Hance WC, Stein F, Ott DA, Jefferson LS, et al. Management of postoperative chylopericardium in childhood. Am J Cardiol 1989; 63:1416-8. 